\title{
Business Integrity v. Business Efficiency: The Corporate Opportunity Doctrine in
}

\section{China}

\section{Dr Fang Ma, Senior Lecturer at the University of Portsmouth}

\begin{abstract}
This paper assesses the application of the nascent corporate opportunity doctrine in China by comparison with its well-established English counterpart; in particular, it evaluates whether the fine balance between business integrity and business efficiency has been struck. It is argued that the scope of application of the corporate opportunity doctrine in China should be extended and the rules on the burden of proof should be amended. Moreover, a stricter approach should be adopted by the Chinese judiciary for the purpose of protecting the company's interests and enhancing business integrity.
\end{abstract}

\section{Introduction}

The corporate opportunity doctrine has existed in the United Kingdom for a long period of time at common law and it is now codified in the Companies Act 2006 (the "CA2006"). By contrast, this doctrine was first introduced into China under the Chinese Company Law 2005 (the "CCL 2005") ${ }^{1}$ as one of the fiduciary duties imposed on directors and senior managers of a company. Art 149(5) of the CCL 2005 provides that "Directors and senior managers, without the approval of shareholder meeting, must not take advantage of their positions to acquire business opportunities for themselves or any other person, or to engage in business identical to the company's business for the benefit of themselves or any other person". It aims to prevent directors and senior managers from taking advantage of the company's opportunities and information unless it is approved by the shareholder meeting.

The current rules under the CCL 2005 provide very basic legal framework; for instance, they only apply to directors and senior managers; supervisors and controlling shareholders are excluded. Moreover, the approval of shareholder meeting, instead of the board of directors, is required for the use of corporate opportunities. The process for obtaining approval is long, cumbersome and inefficient; as such, many corporate opportunities which were not promptly taken up by the company would be wasted or delayed if directors could not get the

${ }^{1}$ The Company Law of the People's Republic of China 2005 was adopted at the $18^{\text {th }}$ session of the Standing Committee of the $10^{\text {th }}$ National People's Congress on 27 October 2005. It became effective from 1 January 2006. 
shareholder meeting's approval in time. If, however, directors could seize corporate opportunity without much restriction, the company's interests and business integrity would be at great risk. Thus, the challenges in applying this doctrine in both jurisdictions are: to what extent does the law allow directors to take advantage of corporate opportunities which they came across while being directors of the company? In other words, how could directors make full use of corporate opportunity or information without compromising their duties to protect the interests of the company? This is essentially a question of striking the delicate balance between maintaining business integrity and enhancing business efficiency.

This paper assesses the application of the nascent corporate opportunity doctrine in China by comparison with its well-established English counterpart; in particular, it evaluates whether the fine balance between business integrity and business efficiency has been struck. Section 1 analyses the corporate opportunity doctrine in England at common law and under section 175 of the CA 2006. Section 2 considers directors' general duties in China, including the duty of loyalty and the duty of diligence. Further reforms are proposed by learning from the English law on directors' duties. Section 3 appraises the scope of application of the corporate opportunity doctrine under Art 149(5) of the CCL 2005; in particular, it focuses on whether its application should be extended to supervisors and controlling shareholders. Section 4 examines recent cases and analyses the standards which have been used by Chinese judiciary in determining whether the corporate opportunity doctrine has been breached. It is concluded that the introduction of corporate opportunity doctrine in China is of great significance in enhancing directors' duties and improving the protection of the company's interests; however, the current rules need to be reformed in order to strike a proper balance between maintaining business integrity and enhancing business efficiency. The scope of application of the doctrine is narrow and the judiciary has adopted a relaxed attitude towards directors' misconduct; it can be argued that the current rules favour enhancing business efficiency over maintaining business integrity. It is proposed that its scope of application needs to be broadened and the circumstances where corporate opportunity is abused should be more clearly defined. Moreover, the power of authorisation should be granted to the board of directors in addition to the shareholder meeting.

\section{The corporate opportunity doctrine in England}


In England, directors were under the duties to avoid conflicts of interests (no-conflict rule) and not to make secret profits from their positions (no secret profit rule) at common law. The courts traditionally have taken a strict approach in applying these rules ${ }^{2}$. In Regal (Hastings) Ltd $v$ Gulliver $^{3}$ it was held that the directors should return the profits to the company because they had obtained their profits by reason and in the course of the execution of their office as directors. It made no difference whether the company itself was incapable of taking up the opportunity. A corporate opportunity was regarded as a company's asset which might not be misappropriated by the directors. This rule equally applies to the situations where a director came across an opportunity personally instead in his capacity as director. In Industrial Development Consultants Ltd (IDC) v Cooley ${ }^{4}$ Cooley was a managing director of IDC and he was actively involved in negotiations with the Eastern Gas Board (EGB) to secure certain construction contracts for IDC. It became clear that EGB was not prepared to contract with IDC. One year later, Cooley resigned from IDC and took the same contracts offered by EGB. It was held that Cooley breached the no secret profit rule and he was liable to account as information came to him while he was a managing director of the company. This strict approach could deter directors from pursuing their own interests at the expense of the company; nevertheless, it has been strongly criticised by Lowry \& Edmunds as being too harsh on directors and it unduly curbs entrepreneurial freedom to compete with companies ${ }^{5}$.

These no-conflict and no-profit rules are now codified in Section 175 of the Companies Act 2006, which provides that a director must "avoid a situation in which he has, or can have, a direct or indirect interest that conflicts, or possibly may conflict with the interests of the company". Section 175 also applies to the exploitation of any property, information or opportunity and it is immaterial whether the company could take advantage of it. This approach aims to prevent directors from pursuing their own interests at the expense of their company.

Compared with the strict English approach, a more relaxed and flexible approach to the corporate opportunity doctrine is adopted in other common law jurisdictions such as Canada and Australia. The courts would consider the line of business of the particular company and the good faith of the director in question when determining whether or not a director has

\footnotetext{
${ }^{2}$ In Bray v Ford [1896] AC 44, Lord Herschell held that "a person in a fiduciary position... is not... entitled to make a profit; he is not allowed to put himself in a position where his interest and duty conflict". 3 [1942] 1 All ER 378

4 [1972] 1 WLR 443

${ }^{5}$ Lowry \& Edmunds, "The No Conflict- No Profit Rules and the Corporate Fiduciary: Challenging the Orthodoxy of Absolutism" [2000] Journal of Business Law 122.
} 
misappropriated a corporate opportunity ${ }^{6}$. A few English court decisions have also shown support for a flexible approach. In Island Export Finance Ltd $v$ Umunna $^{7}$, the managing director had resigned due to dissatisfaction with the company before the completion of transaction complained of. He then set up his own company and secured a new contract for it regarding the same transaction. It was held that no conflicts of interests occurred and the director was allowed to keep the profit. Hutchinson $\mathrm{J}$ held that it was plainly in the public interest that directors should be free to exploit an opportunity in a new position. Similarly it was held in Balston Ltd $v$ Headline Filters $L t d^{8}$ that a director did not breach his fiduciary duty by setting up a business in competition with his former company after his resignation, even where the intention to commence business was formed prior to the resignation. This more relaxed approach may promote the business activities but at the same time there is a greater risk of the company being exploited by its own directors.

This duty to avoid conflicts of interest is not infringed if the transaction has been effectively authorised by disinterested directors ${ }^{9}$ or if the situation cannot reasonably be regarded as likely to give rise to a conflict of interest ${ }^{10}$. There is no need to gain shareholders' approval prior to entering into transactions with third parties where the interests of directors conflict with those of the company. Authorisation is effective only if the following two conditions are met $^{11}$. Firstly, the director in question or any other interested director is not counted towards the quorum and any requirement as to the quorum at the meeting at which the matter is considered is met. Second, the matter was agreed to without counting the votes by the director in question or any other interested director. There are different rules for private companies and public companies. In a private company, authorisation may be given by the directors if nothing in the company's constitution invalidates such authorization ${ }^{12}$. In a public company, authorization may take place where its constitution enables the directors to authorise the matter and the matter is proposed to and authorised by them in accordance with the constitution ${ }^{13}$.

\footnotetext{
${ }^{6}$ Peso Silver Mines v Cropper (1966) 58 DLR (2d)1; Queensland Mines Ltd v Hudson (1978) 52 ALJR 399.

${ }^{7}$ [1986] BCLC 460.

8 [1990] FSR 385.

${ }^{9}$ Section 175(4)(b), CA 2006.

${ }^{10}$ Section 175(4)(a), CA 2006.

${ }^{11}$ Section 175(6), CA 2006.

${ }^{12}$ Section 175(5), CA 2006.

${ }^{13}$ Ibid.
} 
Furthermore, a director, who breached his duty under s 175, will not be liable to return the profits if the breach has been ratified by a company's resolution ${ }^{14}$. Where the resolution is proposed at a meeting, it is passed only if the necessary majority is obtained disregarding votes in favour of the resolution by the director (if he is a member of the company) and any member connected with him ${ }^{15}$. The director or any such member is not prevented from attending, being counted towards the quorum and taking part in the meeting where the decision is considered. The strict application of the corporate opportunity doctrine in the UK has been moderated by the possibility of authority by the board of directors and the ratification by the general meeting. It appears that the courts still take a strict approach towards the corporate opportunity doctrine ${ }^{16}$; nevertheless, such a rigorous approach is moderated to some extent by the potential authorisation by the board of directors and the ratification of a breach of such duties by the shareholder meeting.

\section{Directors' general duties in China}

Directors owe the duty of loyalty and the duty of diligence to their company under the CCL 2005; however, neither duty is well defined. The Chinese Company Law 1993 (the "CCL 1993") ${ }^{17}$, which was replaced by the CCL 2005, introduced the concept of a director's duty of loyalty to the company in order to ensure that directors acted in good faith and loyalty in managing a company. ${ }^{18}$ It required directors to faithfully perform their duties and maintain the interests of the company, and not to take advantage of their positions for personal benefits. ${ }^{19}$ This was similar to the concept of directors' fiduciary duties in England; ${ }^{20}$ however, there was no clear definition of "faithfully" or "the interests of the company". Both directors and shareholders therefore did not have a clear concept of what directors were

\footnotetext{
${ }^{14}$ Section 239(2), CA 2006.

${ }^{15}$ Section 239(4), CA 2006.

16 Prentice, "The Corporate Opportunity Doctrine" [1974] MLR 464; Prentice \& Payne, "The Corporate Opportunity Doctrine" (2004) 120 LQR 198; Lowry, "Judicial Pragmatism: Directors' Duties and Post-resignation Conflicts of Duty" [2008] JBL 83.

${ }^{17}$ The Company Law of the People's Republic of China 1993 was adopted at the 5th session of the Standing Committee of the Eighth National People's Congress on 29 December 1993. It became effective from 1 January 1994.

${ }^{18}$ Directors' duties in limited liability companies are listed in Articles 59-63 of the CCL 1993 which also apply to directors in joint stock companies: Art 123, CCL 1993.

${ }^{19}$ Art 59 (1), CCL 1993.

${ }^{20}$ Ping Jiang \& Liufang Fang, Company Law [Gongsi Fa] (Law Press, 2003), p.213.
} 
required to do whilst the courts and judges found it difficult to enforce these duties in practice. $^{21}$

The CCL 2005 has not resolved these inadequacies to any great extent. Directors now owe a duty of loyalty to the company and they must comply with laws, administrative regulations and the articles of association. ${ }^{22}$ Article 148 states that "A director shall abide by laws, administrative regulations and articles of association of the company and shall have the fiduciary and diligent duties to the company." Art 149 simply aggregates the previous provisions under the CCL $1993^{23}$ by providing a detailed list of activities that directors, supervisors and senior managers are not allowed to engage in, such as misappropriating company's funds or depositing the company's funds into an account in his own or other's name $^{24}$. They are prohibited from self-dealings; for example, they should not, in violation of the company's articles of association or without the consent of the shareholder meeting or the board of directors, enter into contracts or carry out transactions with the company ${ }^{25}$. Similarly, they should not take advantage of their position to acquire business opportunities for himself or any other person, or to engage in business identical to the company's business for the benefit of themselves or any other person (the corporate opportunity doctrine) $)^{26}$. They should not lend the company's fund to others or provide any guarantee to any other person by using the company's property ${ }^{27}$. Moreover, they are prohibited from taking commissions on the transactions between their company and others, or disclosing the company's secrets without permission $^{28}$. Above all, a catch-all provision is included in Art 149 (8) where directors and senior managers are refrained from undertaking "other acts that breach their duty of loyalty". It is argued that the duty of loyalty, although similar to the concept of fiduciary duty in England, is not clearly defined in China; further judicial interpretations are required to clarify the meaning and the scope of this duty.

The duty of diligence is of great importance for the protection of the interests of shareholders and the company. As directors have discretion to propose business strategies and prepare reports for shareholder meetings, the lack of this duty may easily lead to their misuse of

\footnotetext{
${ }^{21}$ Jinzhu Yang, "The Role of Shareholders in Enforcing Directors' Duties: A Comparative Study of the UK and China: Part 1 " (2006) 17 I.C.C.L.R 318, 326.

${ }^{22}$ Art 148, CCL2005.

${ }_{23}$ Articles 60-62, CCL 1993.

${ }^{24}$ Art 149(1), CCL 2005.

${ }^{25}$ Art 149(4), CCL 2005.

${ }^{26}$ Art 149(5), CCL 2005.

${ }^{27}$ Art 149(3), CCL 2005.

${ }^{28}$ Art 149(6), CCL 2005.
} 
power and an infringement of shareholders' interests. Directors' duty of diligence did not exist under the CCL 1993. The CCL 2005 fills this gap by clearly imposing such duty on directors $^{29}$; however, unlike the duty of loyalty, it fails to address any specific rules, such as what the duty of diligence really means and which types of standards should be adopted. For instance, it does not specifically require directors to have any expertise or knowledge of the company's business, the lack of which would most probably put the company's interests at risk.

By contrast, a director must exercise reasonable care, skill and diligence under the English Companies Act 2006. This means the care, skill and diligence that would be exercised by a reasonably diligent person with the general knowledge, skill and experience that may reasonably be expected of a person carrying out the functions carried out by the director in relation to the company ${ }^{30}$, and the general knowledge, skill and experience that the director has $^{31}$. The former sets an objective minimum standard of a reasonably diligent person who has taken on the office of director, taking into account of the functions undertaken. The latter sets a subjective standard in relation to the personal attributes of the director, which may in some circumstances raise the objective minimum standard.

More detailed guidance is provided at common law on the duty of care, skill and diligence. In Re Barings Plc $(N o .5)^{32}$, a number of senior directors failed to supervise a rogue trader within the bank, which resulted in a substantial amount of financial loss and the collapse of the bank. These directors were found to be unfit and disqualified. It was held that directors, both collectively and individually, had a continuing duty to acquire and maintain a sufficient knowledge of the company's business to enable them to discharge their duties. Whilst directors, subject to the articles of association, are entitled to delegate particular functions to those below them in the management chain and to trust their competence and integrity to a reasonable extent, the delegation of power does not absolve a director from the duty to supervise the discharge of the delegated functions. It is argued that the English approach, which combines objective and subjective standards for this duty, will be of great benefit to Chinese legislators because it has been well established and tested in practice over a long period of time.

\footnotetext{
${ }^{29}$ Art 148, CCL 2005.

${ }^{30}$ Section 174(2)(a), CA 2006.

${ }^{31}$ Section 174(2)(b), CA 2006.

32 [2000] 1 BCLC 523.
} 


\section{The corporate opportunity doctrine in China: the scope of application}

The corporate opportunity doctrine did not exist under the CCL 1993 but directors and managers must not undertake business for themselves or others business similar to that of the company; any income from such activities should belong to the company (the "no-competing rule") ${ }^{33}$. The application of this no-competing rule was very strict in the sense that under no circumstances could directors and managers undertake business similar to that of their company. The breach of this duty did not depend on whether the company had approved it or not. The current no-competing rule is contained in Art 149(5) of the CCL 2005 and it is more flexible than its predecessor in the way that directors, with the approval of the company, can compete with the company and undertake similar business.

The corporate opportunity doctrine was introduced into China under the CCL 2005 and it exists alongside the no-competing rule. Corporate opportunity was defined by leading academic Liu as the business opportunity that directors or senior managers obtained when they were carrying out company's business. ${ }^{34}$ The introduction of corporate opportunity doctrine has great implications on the protection of the company's interests; however, it is argued that the current provisions are theoretical and many questions are left unanswered ${ }^{35}$. For instance, it is unclear whether the rule applies to de facto directors, shadow directors, supervisors and controlling shareholders. Further guidance is required on how corporate opportunity is defined and in what circumstances directors can take advantage of the opportunity. Moreover, it does not give the board of directors the power to authorise the potential conflict of interests and directors' use of corporate opportunities.

\section{(1) Directors and Senior Managers}

The corporate opportunity doctrine under Art 149 only applies to directors and senior managers ${ }^{36}$. A director refers to de jure director who has been legally appointed and there is

\footnotetext{
${ }^{33}$ Art 61(1) of the CCL 1993 provides that "Directors and Managers must not undertake business for themselves or others business similar to that of the company. They must not infringe the company's interests. Any income from the above activities belongs to the company".

${ }^{34}$ Liu Junhai, The Protection of Shareholders' Rights in Joint Stock Companies [Gufen Youxian Gongsi Gudongquan de Baohu] China Law Press [Zhongguo Falu Chubanshe], 2004], pp 172-173.

${ }^{35}$ Feng Guo, "A study of Prohibiting the Abuse of Corporate Opportunities” [Jinzhi Cuanduo Gongsi Jihui Guize Tanjiu], Chinese Legal Studies [Zhongguo Faxue], 2010, Issue 1, p 96.

36 "Senior managers" are defined in Art 217 (1) of the CCL 2005.
} 
no detailed classification of directors in China. It indicates that de facto directors and shadow directors are not covered by this duty. By comparison, a director under English law is more broadly defined and it includes "any person occupying the position of a director, by whatever name called." 37 The title is not the determining factor in deciding whether a person is a director; a director may appear as a de jure director ${ }^{38}$, de facto director ${ }^{39}$ and shadow director $^{40}$. It is incisively argued by Feng that the corporate opportunity doctrine should extend to de facto and shadow directors who carry out the functions as de jure directors, taking into account their important roles in the company ${ }^{41}$.

A senior manager is defined as "deputy-manager, finance manager and the director's secretary at listed companies, or others specified in the company's articles of association." 42 The scope of senior manager is clarified in the case of Beijing Jinghua Sifang Trading Ltdv Yu Qian ${ }^{43}$. The defendant Yu Qian was a branch manager of the claimant Jinghua Sifang Ltd. He made a profit by introducing the contract which the claimant had cancelled to another company Yibo Ltd. It was held that the defendant was not subject to the corporate opportunity doctrine under Art 149(5) because the definition of senior manager includes the company's manager and deputy manager who have been appointed by the board of directors or the shareholder meeting. It does not include branch managers within the company such as the defendant in this case.

Another question arises as to whether the corporate opportunity doctrine applies to directors or senior managers who have retired or left the company. In England, a director continues to be subject to the duty to avoid conflict of interests in relation to company property, information or opportunity after he ceases his appointment. ${ }^{44} \mathrm{~A}$ director is therefore prevented from taking advantage of a situation by simply resigning from the company's board of directors. Jiang strongly argues that the same approach should be followed in China

\footnotetext{
${ }^{37}$ Section 250, CA 2006.

${ }^{38}$ A de jure director can be appointed by an ordinary resolution at the general meeting. When he is successfully appointed his details must be kept at the company's registered office and also registered at the Companies House. Re CEM Connections (2000) BCC 917.

${ }^{39}$ A de facto director has not been formally appointed as such but has undertaken the functions of directors. Re Hydrodam (Corby) Ltd [1994] BCC 161; Re Paycheck Services 3 Ltd [2011] 1 BCLC 141.

${ }^{40}$ A shadow director is defined in s 251(1) of the CA 2006 as a person in accordance with whose directions or instructions the directors of a company are accustomed to act. However, a person is not deemed to be a shadow director by reason only that the directors act on advice given by him in a professional capacity (s 251(2)). See Secretary of State v Deverell [2000] BCC 1057.

${ }^{41}$ See Feng Guo (2010), p 105.

${ }^{42}$ Art 217 (1), CCL 2005.

${ }^{43}$ [Beijing Jinghua Sifang Maoyi Youxian Gongsi yu Yuqian Gaoji Guanli Renyuan Sunhai Gongsi Liyi Peichang Jiufen An] Beijing No 1 Intermediate People's Court (2009), No 13800.

${ }^{44}$ Section 170(2), CA 2006. David Milman, "Legislative Comment Directors and the Transition to the New Regime" (2007) Company Law Newsletter, Issue No 8, p.3
} 
and directors who have left the company should still be subject to this duty as long as they came across the information when they were directors of the company ${ }^{45}$. For the purpose of protecting the company's interests, it is sensible to follow the English approach by extending this duty to those who have ceased appointment with the company.

\section{(2) Supervisors}

It is alarming that supervisors are not subject to the fiduciary duties in Art 149 and in particular the corporate opportunity doctrine in Art 149 (5), taking into account that they play an important role in supervising the board of directors and they also have access to the company's sensitive information and opportunities. The CCL 2005 requires the establishment of shareholders' general meetings, a board of directors and a board of supervisors for both limited liability companies and joint stock companies in China. ${ }^{46} \mathrm{~A}$ general meeting is regarded as the supreme organ of authority of a company, with extensive powers to exercise control over the company's affairs. ${ }^{47}$ The board of directors is responsible for managing the company, ${ }^{48}$ while a board of supervisors has the right to supervise corporate management and the activities of directors and managers. ${ }^{49}$ The two-tier system in China aims to create a hierarchical system with a supervisory board above a board of directors in order to put restraints on directors' power and therefore to reduce agency costs.

Supervisors are given many powers; for instance, they are entitled to check the company's financial accounts, propose to dismiss directors or senior managers ${ }^{50}$, propose to hold shareholder meeting ${ }^{51}$, and initiate litigation against directors upon the request of shareholders. ${ }^{52}$ In the light of their significant roles in maintaining good corporate governance in the company, it is correctly argued by Feng that supervisors should not be allowed to take advantage of opportunities which belong to the company and therefore the corporate opportunity doctrine should equally apply to them. ${ }^{53}$ This argument was supported

\footnotetext{
45 Jiang Daxing, "Duties of Directors Who Have Ceased Appointment - The Amendments of Chinese Company Law" [Dongshi Liren Yiwu Lifa Guize Yanjiu - Jianlun Woguo Gongsifa zhi Xiugai] (2001) Law Review [Faxue Pinglun], Issue No 5 .

${ }^{46}$ S Shim, "Corporate Governance Reform in China" (2005) 26 Comp Law 375, 376.

${ }^{47}$ Art 100, CCL 2005.

${ }^{48}$ Art 109, CCL 2005.

${ }^{49}$ Art 119, CCL 2005.

${ }^{50}$ Art 54 (2), CCL 2005.

${ }^{51}$ Art 54 (4), CCL 2005

${ }^{52}$ Art 54 (6) and Art 152, CCL 2005.

${ }^{53}$ See Feng Guo (2010), p 107.
} 
by the judgment in the case of Liu $v \mathrm{Li}^{54}$. The defendant Li was a supervisor and Assistant to General Manager of Wanpeng Ltd; he had great influence on company's management decisions. It was alleged that the defendant set up another company Fumoxiang Ltd which operated similar business to Wanpeng Ltd. The Court of Appeal held that the defendant, as a supervisor of the company, did not breach the corporate opportunity rule because Art 149(5) only applies to a director or senior manager. The outcome of this case would be completely different and the company's interests would have been better protected if Art 149 applied to supervisors.

(3) Should the corporate opportunity doctrine apply to controlling shareholders?

It is clear that the fiduciary duties in Art 149 do not apply to controlling shareholders. Controlling shareholders are defined as those who hold more than $50 \%$ of the company's share capital and those who have a great influence on the outcome of shareholder resolution even though they do not hold a majority of shares of the company ${ }^{55}$. It is important to impose some restrictions on controlling shareholders' conduct in China, not least for the protection of minority shareholders' interests. This is particularly significant due to the shareholding structure in many companies which are controlled by majority shareholders. The shareholding structure is highly concentrated in the hands of majority shareholders in most joint stock companies, even in listed companies. ${ }^{56}$ Shareholders were generally free to act in their own interests and owed no fiduciary duties to other shareholders or the company under the CCL 1993. ${ }^{57}$ Majority shareholders' interests may be consistent with those of the minority but practical evidence suggests the former may try to take advantage of their controlling position, in particular, in large joint stock companies. ${ }^{58} \mathrm{~A}$ restriction on their conduct therefore is essential to prevent their abuse of power and thereby protect the interests of minority shareholders and the company.

\footnotetext{
${ }^{54}$ [Liubin yu Li Zhanjun Jianshi Sunhai Gongsi Liyi Jiufen An] Beijing No 1 Intermediate People's Court (2010) No 1099.

${ }_{55}^{55}$ Art 217 (2), CCL 2005.

56 Jin Xin, "Listed Companies Shareholding Structure and Corporate Governance" [Shangshi Gongsi Guquan Jiegou Yu Gongsi Zhili], China Finance Press [ Zhongguo Jinrong Chubanshe], 2005.

${ }^{57}$ Guoping Zhang, "The Defects of the Shareholders' Litigation System in China” [Chuyi Woguo Gudong Susong Zhidu de Que yu Shi] (Nanjing Social Science, No.11, 2002).

${ }^{58}$ Sibao Shen \& Jing Jia, "Will the Independent Director Institution Work in China” (2005) 27 Loy.L.A.Int'1 \& Comp. L. Rev.223, at 232.
} 
Under the CCL 2005, shareholders, including controlling shareholders, must exercise their voting rights according to law. They must not abuse their rights which would infringe the interests of the company or other shareholders; otherwise, they will be held liable for compensation to the company or shareholders. ${ }^{59}$ Specifically, Art 21 stipulates that a company's controlling shareholders, de facto controllers ${ }^{60}$, directors, supervisors or senior managers shall not use their affiliated relationship to harm the interests of the company. They will be responsible for compensation if this provision is breached. The duties of controlling shareholders therefore have been strengthened to tackle the serious de facto control problems and to ease their oppression against minority shareholders. These provisions, however, are very general and difficult to apply in practice; for example, the duties in Articles 20 and 21 are not specified and the only remedy available is compensation.

In addition to the fiduciary duties in the CCL 2005, it is clearly stated in the Code of Corporate Governance for Listed Companies in China ${ }^{61}$ that controlling shareholders in a listed company owe fiduciary duties to the company and other shareholders; they must not make profits by taking advantage of their positions in the company ${ }^{62}$. More precisely, the controlling shareholders of listed companies are prohibited from engaging with similar or identical business with that of their companies ${ }^{63}$. It is suggested that controlling shareholders should be subject to the corporate opportunity doctrine under the CCL 2005 in order to effectively protect the interests of companies. Further judicial interpretations are therefore needed to extend the scope of application of this doctrine.

(4) Authorisation

\footnotetext{
${ }^{59}$ Art 20, CCL 2005.

${ }^{60}$ The de facto controller is defined as a person "who is not a shareholders of a company but controls the company's act through investment relationships, agreements or other arrangements. Art 217(3), CCL 2005.

${ }^{61}$ [Shangshi Gongsi Zhili Zhunze], Issued by China Securities Regulatory Commission, State Economic and Trade Commission on $7^{\text {th }}$ January 2001.

${ }^{62}$ Art 19 of the Code of Corporate Governance for Listed Companies in China states that "The controlling shareholders owe a duty of good faith towards the listed company and other shareholders. The controlling shareholders of a listed company shall strictly comply with laws and regulations while exercising their rights as investors, and shall be prevented from damaging the listed company's or other shareholders' legal rights and interests, through means such as assets restructuring, or from taking advantage of their privileged position to gain additional benefit".

${ }^{63}$ Art 27 of the Code of Corporate Governance for Listed Companies in China provides that "A listed company's business shall be completely independent from that of its controlling shareholders. Controlling shareholders and their subsidiaries shall not engage in the same or similar business as that of the listed company. Controlling shareholders shall adopt efficient measures to avoid competition with the listed company".
} 
The approval of shareholder meeting is required for authorising directors' conflict of interests under Chinese company law ${ }^{64}$. It is argued that the board of directors should be entitled to approve the potential conflict of interests because it is usually less costly and less timeconsuming to hold a board meeting than a shareholder meeting. The different rules on authorisation in England for private companies and public companies, which are discussed in Section 1, should also be considered for adoption in future Chinese law reforms in the light of different natures of these companies.

\section{The application of corporate opportunity doctrine in China - Case Analysis}

According to the research carried out by $\mathrm{Hou}^{65}$, a total of ten cases were decided in China between 2006 and $2011^{66}$ where directors or senior managers were sued for taking advantage of corporate opportunities. Only two ${ }^{67}$ out of these ten cases were successful. In those eight unsuccessful cases, the courts in two cases held that the claimant company had lost the business opportunity ${ }^{68}$; the court in one case held that the business opportunity did not belong to the company ${ }^{69}$; it was held in the remaining five cases that the claimant could not provide sufficient evidence to prove that the defendant took advantage of corporate opportunity ${ }^{70}$. Unfortunately none of the cases provides any guidance on whether or when a corporate

\footnotetext{
${ }^{64}$ Art 149, CCL 2005.

${ }^{65}$ Hou Huaixia, "The Judicial Application of 'Corporate Opportunity Doctrine' in China” [Woguo 'Jinzhi Cuanduo Gongsi Jihui Yuanze' Sifa Shiyong Yanjiu] Studies in Law and Business [Fa Shang Yanjiu], 2012, Issue No 4, p 149.

${ }^{66}$ The cases were collected between 1 January 2006 and 1 November 2011 from two leading databases: http://www.lawyee.net/ and http://chinalawinfo.com/.

${ }^{67}$ Wuxi Weiyan Ltd $v$ Xu [Wuxi Weiyan Youxian Gongsi Su Xu Naihong Deng Maimai Hetong Jiufen An] JiangSu Wuxi Binhu District People's Court (2006) No 0810. Fujian Yatong New Technology Ltd v Liu [Fujian Yatong Xin Cailiao Keji Gufen Youxian Gongsi Su Liu Daomin Deng Sunhai Gongsi Quanyi Jiufen An], Liaoning Shenyang Intermediate People's Court [2006] No 1.

${ }^{68} \mathrm{Liu} v \mathrm{Li}$ [Liubin Yu Li Zhanjun Jianshi Sunhai Gongsi Liyi Jiufen An] Beijing No 1 Intermediate People's Court (2010) No 1099. Ningbo Kejiyuan Xinhua Information Technology Ltd v Xu Lijian et al [Ningbo Keji Yuanqu Xinhua Xinxi Jishu Youxian Gongsi Su Xu Lijian Deng Sunhai Gongsi Quanyi An] Ning Bo Yinzhou People's Court (2007) No 2.

${ }^{69}$ Beijing Jinghua Sifang Trading Ltd v Yu Qian [Beijing Jinghua Sifang Maoyi Youxian Gongsi yu Yuqian Gaoji Guanli Renyuan Sunhai Gongsi Liyi Peichang Jiufen An] Beijing No 1 Intermediate People's Court (2009) No 13800.

70 Shanghai Pharmaceutical Co Ltd v. Mao [Shanghai Shengyao Yiyao Youxian Gongsi Su Mao Mo Dongshi, Jianshi, Gaoji Guanli Renyuan Sunhai Gongsi Liyi Jiufen Peichang An] Shanghai Pudong Xinqu People's Court (2008) No 3719. Beijing Zhongming International Logistics Ltd v. Tian Qiang et al [Beijing Zhongming Guoji Wuliu Youxian Gongsi Yu Tian Qiang, Wei Xiaoming, Ding Shan, O Yang Qi Sunhai Gongsi Liyi Jiufen An] Beijing No 2 Intermediate People's Court (2009), No 02263. Ningbo Dahongying Pharmaceutical Supply Ltd v. Shen Yongren Director and Senior Manager [Ningbo Da Hongying Yiyao Gongxiao Youxian Gongsi Yu Shen YongRen Gongsi Dongshi, Gaoji Guanli Renyuan Sunhai Gongsi Liyi Peichang Jiufen Shangsu An] Zhejiang Ningbo Intermediate People's Court (2009) No 1212; Xuzhou Dakang Electrical Control Techonology Ltd v Li Wenhua [Xuzhou Dakang Diankong Keji Youxian Gongsi Yu Li Huawen Deng Sunhai Gongsi Liyi Jiufen Shangsu An] Jiangsu Xuzhou Intermediate People's Court (2010) No 0355. Fujian Yatong New Material Technology Ltd v. Liu Daomin et al [Fujian Yatong Xin Cailiao Keji Gufen Youxian Gongsi Su Liu Daomin Deng Sunhai Gongsi Quanyi Jiufen An] Liaoning Shenyang Intermediate People's Court [2006] No 1.
} 
opportunity can be reasonably used, for instance, with the approval of shareholder meeting or board meeting.

As stated above, the claimant company successfully sued its director or senior manager for taking advantage of the corporate opportunities in two cases. In Wuxi Weiyan Ltd $v$ Xu, the defendant, who was a senior manager of the claimant company, set up his own company and transferred the claimant's properties to himself at an undervalue. It was held that the defendant violated the company's articles of association and conducted transaction with the claimant without its approval. As such, the claimant company's interests were clearly infringed by the transaction. ${ }^{71}$ In Fujian Yatong New Technology Ltd $v$ Liu, the defendant, whist working as director of the claimant, set up another company to compete with the claimant over the same business. It was held that the defendant had breached the corporate opportunity doctrine under Art 149 of the CCL $2005^{72}$.

The court in five cases held that the defendants were not liable for breaching the corporate opportunity doctrine because the claimant could not provide sufficient evidence to prove that the defendants took advantage of corporate opportunities. The judgments clearly indicate that the burden of proof lies on the claimant who alleged that the defendants infringed the company's interests by taking advantage of corporate opportunity. In the case of Shanghai Pharmaceutical Co Ltd v Mao, the claimant sued its director, supervisor and senior managers for infringing the company's interests. An important client of the claimant terminated the project with it and then started working with another company which was set up by the defendants. This case was unsuccessful because the claimant could not provide sufficient evidence to prove that the company was incorporated or managed by the defendants. ${ }^{73}$ Similarly, it was alleged in Beijing Zhongming International Logistics Ltd v Tian Qiang et al that the defendants incorporated their own company and seized the claimant's business opportunity by conducting the same business as that of the claimant. This case was unsuccessful mainly because the claimant could not prove that any loss was incurred on the claimant. ${ }^{74}$ In Beijing Dadao Changsheng Techonology Ltd $v$ Beijing Henhua Tengxin Techonology Ltd and Its Senior Managers, the claimant did not have sufficient evidence to

\footnotetext{
71 [Wuxi Weiyan Youxian Gongsi Su Xu Naihong Deng Maimai Hetong Jiufen An] JiangSu Wuxi Binhu District People's Court (2006) No 0810.

72 [Fujian Yatong Xin Cailiao Keji Gufen Youxian Gongsi Su Liu Daomin Deng Sunhai Gongsi Quanyi Jiufen An], Liaoning Shenyang Intermediate People's Court [2006] No 1.

73 [Shanghai Shengyao Yiyao Youxian Gongsi Su Mao Mo Dongshi, Jianshi, Gaoji Guanli Renyuan Sunhai Gongsi Liyi Jiufen Peichang An] Shanghai Pudong Xinqu People's Court (2008) No 3719.

74 [Beijing Zhongming Guoji Wuliu Youxian Gongsi Yu Tian Qiang, Wei Xiaoming, Ding Shan, Ou Yang Qi Sunhai Gongsi Liyi Jiufen An] Beijing No 2 Intermediate People's Court (2009) No 02263.
} 
prove the defendant (who was a senior manager of the claimant) was conducting the same business as that of the claimant ${ }^{75}$. It is concluded from the judgments of these cases that the claimant company bears the burden of proof, which makes it even more difficult to hold the defendants liable for the breach of their fiduciary duties. It would be helpful if the test of liability based on presumed fault could be adopted in some circumstances so that the defendants are presumed to be liable unless they can prove otherwise.

It can be argued that the Chinese judiciary has adopted a less rigid approach to corporate opportunity compared to the English counterpart. In Beijing Jinghua Sifang Trading Ltd $v$ Yu $\operatorname{Qian}^{76}$, the defendants were senior managers of the claimant. They introduced to another company Yibo Ltd the contract which the claimant had withdrawn and in return they received a commission of RMB 100,000. The claimant sued the defendants for infringing the company's interests and sought compensation. It was held that the defendants did not take advantage of the claimant's opportunity because they knew the client information about Yibo Ltd before their employment with the claimant and they played no substantial part in the claimant's withdrawal of the contract. Similarly, in Ningbo Kejiyuan Xinhua Information Technology Ltd $v$ Xuli et $a l^{77}$, the claimant sued the defendants for infringing the company's interests. The claimant terminated the contract with Jiaotou Ltd because it was unable to complete the project. The defendants, who were senior managers of the claimant, agreed to work on the same project in their own capacity and signed the contract with Jiaotou Ltd. It was held that the defendants did not breach their duties under Art 149(5) because the claimant had given up the opportunity; as such, the opportunity no longer belonged to the claimant and the defendant did not take advantage of the opportunity or infringe the claimant's interests. This is in stark contrast with the strict English approach where a director is prevented from taking advantage of the company's information or opportunity and it is immaterial whether the company could take $i^{78}$. If both cases were tried under English law, the defendants would most probably be held liable for breaching their fiduciary duties under section 175 of the CA 2006, taking into consideration that they came across the information whilst working for the company and that the board's authorisation was not obtained.

\footnotetext{
${ }^{75}$ Beijing Dadao Changsheng Technology Ltd v. Beijing Henghua Tengxin Technology Ltd and its Senior Managers [Beijing Dadao Changsheng Keji Youxian Gongsi Su Beijing Henghua Tengxin Keji Youxian Gongsi Deng Gaoji Guanli Renyuan Jingye Jinzhi Jiufen An] Beijing Haidian District People's Court (2009) No 5924.

76 [Beijing Jinghua Sifang Maoyi Youxian Gongsi yu Yuqian Gaoji Guanli Renyuan Sunhai Gongsi Liyi Peichang Jiufen An] Beijing No 1 Intermediate People's Court (2009) No 13800.

77 [Ningbo Keji Yuanqu Xinhua Xinxi Jishu Youxian Gongsi Su Xu Lijian Deng Sunhai Gongsi Quanyi An] Ning Bo Yinzhou People's Court (2007) No 2.

${ }^{78}$ Aberdeen Rly Co v Blaikie Bros (1854) 1 Macq 461; Cook v Deeks [1916] 1 AC 554.
} 
The analysis of recent cases in China indicates that, by comparison with the English counterpart, the courts have taken a more relaxed approach in identifying whether a director has taken advantage of corporate opportunities. Only in very few cases were the defendants held liable for breaching the corporate opportunity doctrine. This is partly due to the fact that the burden of proof is placed solely on the claimant company. The standards used for determining corporate opportunity and the circumstances for reasonable use of corporate opportunity should be clearly defined. It is proposed that future Judicial Interpretations should be drafted to improve the corporate opportunity doctrine in China as a way of more effectively protecting the company's interests. At the same time, it is essential to strike a proper balance between business morality and business efficiency.

\section{Conclusion}

It is a great step forward by introducing the corporate opportunity doctrine into directors' fiduciary duties in China; however, the current rules merely provide a basic legal framework and they are insufficient to deter directors from seizing corporate opportunities for their personal interests. In terms of the scope of application, it only applies to directors and senior managers; supervisors and controlling shareholders are not covered by this duty. Moreover, the concept of director does not take into account de facto directors and shadow directors. It is recommended that, in order to maximize the protection for a company's interests, the scope of application should be extended and that the classification of different types of directors under English law should be considered for its introduction into Chinese law.

In relation to authorisation, only a shareholder meeting can approve the use of corporate opportunities by directors and senior managers in China. This may be impractical and inefficient as the procedure for holding such meeting is cumbersome and lengthy. It is argued that the board of directors should be entitled to authorise the actual and potential conflict of interests and the use of corporate opportunities. The different requirements for authorisation in private companies and public companies under English law should be considered for future Chinese legislation reforms. 
The narrow scope of application of the corporate opportunity doctrine, the heavy burden of proof on the claimant company and the relaxed approach adopted by the judiciary indicate that the current balance leans towards promoting business efficiency in China. Recent cases also demonstrate that the courts are tolerant towards the behaviours of directors and senior managers; they are reluctant to hold directors' liable and keen to ensure that corporate opportunities are used. As such, the business integrity of directors and senior managers is not strictly maintained. It is argued that the current tolerance of directors' misconduct and the encouragement of directors to make full use of business opportunities stem partially from the country's drive to increase economic performance and partially from the lack of detailed statutory rules as well as the inexperience or incompetence of the judges. In order to enhance both the business efficiency and business integrity in the long run, it is strongly recommended that the current balance should be re-addressed and more emphasis should be placed on maintaining business integrity. In particular, the scope of application of the corporate opportunity doctrine should be expanded and the burden of proof should not entirely be placed on the claimant company. Moreover, a stricter judicial attitude should be adopted for the purpose of protecting the company's interests and enhancing business integrity. 